\title{
Defining disease, segregating race: Sir Raphael Cilento, Aboriginal health and leprosy management in twentieth century Queensland
}

\author{
Meg Parsons
}

In Australia, as elsewhere, modern scientific studies of leprosy were firmly located within contemporary race-based and climatic medical theories, and were closely aligned to the discipline of tropical medicine. ${ }^{1}$ During the interwar period the race-based leprosy theories of doctors Cecil Cook and Sir Raphael Cilento directly informed leprosy management strategies in Queensland, the Northern Territory and Western Australia. ${ }^{2}$ In the Queensland context, the emergence of these racially discriminatory medical theories helped solidify the Queensland government's commitment to spatial segregation as its primary method of managing leprosy. Moreover these theories served to reinforce existing white perceptions about Aboriginal people and re-articulate the idea that Aboriginal ill health was an inescapable consequence of racial weaknesses. Sir Raphael Cilento, well known for his association with tropical medicine and social hygiene in Australia in the first half of the twentieth century, also played a pivotal role in the maintenance and alteration of the Queensland government's Aboriginal leprosy management strategies during the 1930s. ${ }^{3}$ Historians have generally overlooked Cilento's involvement in leprosy management, and perhaps more significantly failed to explore the operations of Fantome Island leprosarium, the institution Cilento helped establish, which was the longest running Aboriginalonly medical segregation facility in Queensland. I will attempt to redress this historical oversight in this article. Firstly I will provide a brief overview of leprosy management strategies in Queensland, then outline the medical theories of Cilento, and lastly chart the establishment and operations of the Aboriginalonly leprosarium on Fantome Island.

\section{Leprosy management in colonial Queensland}

In the late nineteenth century leprosy came to renewed prominence in European and colonial societies including Australia. ${ }^{4}$ Leprosy funds were established, international conferences assembled, and new legislation passed that enabled

1 Worboys 2000: 207-218.

2 Bashford and Nugent 2002: 106-128. See also Briscoe 2003: 142-204; Jacobs 1986: 15-23.

3 Finnane 2007: 215-216.

4 Bashford and Nugent 2002: 106-128. 
governments to medically segregate leprosy patients in 'leper' colonies, lazarets or leprosariums. ${ }^{5}$ Yet there was not a dramatic increase in leprosy sufferers worldwide; rather a heightened consciousness about leprosy resulted in increased diagnosis of the disease. ${ }^{6}$ Leprosy management closely mirrored and merged with the colonial governance of racially coded populations. ${ }^{7}$ Both medical theories and popular discourses attributed the arrival and spread of leprosy to supposedly pathogenic non-white cultures, sometimes indigenous but usually diasporic non-whites. ${ }^{8}$ Misunderstandings of leprosy transmission coupled with racial coding led government authorities to justify and use the policy of segregation as the primary method to control leprosy. ${ }^{9}$

In their pioneering 1970 article, Zachary Gussow and George S Tracy question whether the stigmatism of leprosy sufferers was a historical constant and culturally consistent phenomenon, which emerged as a 'nature' response to a disfiguring and incurable disease. ${ }^{10}$ They convincingly argue that the fear of leprosy was a cultural construct which arose in Western societies in the late nineteenth century as a consequence of colonial expansion. Leprosy was increasingly labelled a disease of non-white peoples (of colonial subjects), which tied in with mounting concerns about colonial rule, racial degeneration and the purity of the white race. As historians Alison Bashford and Maria Nugent have more recently observed, leprosy re-emerged into the collective consciousness of white societies that were already struggling with the consequences of colonialism and the 'changing economies of race'.$^{11}$ While leprosy was not wholly a colonial issue, the disease was nevertheless situated within the discourses of colonial medicine. ${ }^{12}$ The characterisation of leprosy as a non-white disease stimulated a whole array of efforts designed to prevent the spread of the disease to the 'civilised' world, including those introduced to Queensland during the late nineteenth century. ${ }^{13}$

Doctors began to diagnose sporadic cases of leprosy in Queensland from the $1870 \mathrm{~s}$ and 1880s. Although the disease initially appeared to be confined to the Chinese and Pacific Island migrant populations, the infection was soon found amongst the white population of Queensland causing widespread alarm. ${ }^{14}$ The

5 The three terms -leper colony, lazaret and leprosarium - all refer to institutions designed for the medical segregation of leprosy sufferers. However the terms reflect different historical periods and institutions practices. The term leprosarium began to be used in the early to mid twentieth century, drew upon the term sanatorium and highlighted a shift in emphasis from punitive segregation to medical segregation. I will use the term leprosarium throughout the article to avoid confusion. Worboys 2000: 207-218. See also Bashford 2003.

6 Gussow 1989. See also Bashford and Nugent 2002: 106-128.

7 Anderson 2006a, b; Bashford 2003; Bashford and Nugent 2002; Mawani 2003; Vaughan 1991.

8 Deacon 2000: 190-206.

9 Obregon 2002: 95.

10 Gussow and Tracy 1970: 425-449.

11 Bashford and Nugent 2002: 106.

12 Bashford and Nugent 2002: 106.

13 Edmond 2006; Moran 2007; Bashford 2003.

14 This construction, of leprosy as a Chinese disease, was not unique to the Australian context and occurred in other white settler societies including Canada and New Zealand. Markus 1979; Saunders 1989; Evans 1989; Edmond 2006; Moran 2007. 
Queensland government's leprosy control strategies which emerged out of this alarm involved the identification and compulsory isolation of all leprosy patients (irrespective of race) on island-based segregation facilities. The first such facility, Dayman Island leprosarium, was established in Torres Strait in 1889 to house Chinese leprosy sufferers, and over the next 90 years various island sites were used for the purposes of compulsory isolation, detention and treatment of Queensland leprosy sufferers. ${ }^{15}$ From 1907 Queensland's leprosy sufferers were sent to Peel Island, four kilometres off the coast of southern Queensland in Moreton Bay, to the state's first (and only) multi-racial lazaret. In its first year in operation 71 patients were admitted to Peel Island leprosarium; 16 of whom were classified as white, the remainder were declared 'coloured' ${ }^{16}$ The establishment of a multi-racial medical institution in a state known for its racial segregation policies represented a radical departure from norms and government policies and is indicative of how leprosy as a disease was, in the words of historian Megan Vaughan, 'often treated in a thoroughly exceptional' manner. ${ }^{17}$ As she notes, leprosy management broke through 'the usual colonial categorizations of difference' ${ }^{18}$ This was clearly articulated in the compulsory isolation of all leprosy sufferers in Queensland, irrespective of their racial classification, which stood in marked contrast to the Queensland government's venereal disease (VD) policies which required that all Aboriginal VD patients but only a small cohort of the white VD patient population (white female prostitutes in Brisbane) be placed in 'lock hospital' facilities.

Historian Suzanne Saunders has previously argued that the spatial segregation of Aboriginal leprosy sufferers in Northern Australia (Western Australia, the Northern Territory and Queensland) represented an extension of the Aboriginal reserve system by which governments forcibly removed Aboriginal people from one location to another and sought to limit their movement. ${ }^{19}$ However, as the work of Jo Robertson has demonstrated, the creation of island-leprosariums in Queensland during the late nineteenth century was more closely aligned with the anti-Chinese movement, and there was no government or public discussion about leprosy with regards to the Indigenous population in this period..$^{20}$ In this article I argue that it was not until the twentieth century that the Queensland government's strategies of Aboriginal management dovetailed with its management of leprosy. This convergence - of the administrations of health and race - was most fully articulated in the operations of Fantome Island leprosarium, which was established in 1940 by Cilento to house Aboriginal leprosy sufferers.

15 Robertson 1999; Blake 1993.

16 Coloured was a generic term that was applied to Chinese, Pacific Islanders, Javanese, Aboriginal, and Torres Strait Islanders, but in this instance seems to imply non-white, non-Aboriginal. Of the 55 coloured patients admitted in 1907, 47 were Pacific Islanders, four Aborigines, three Chinese and one Indian. Blake 1993.

17 Vaughan 1991: 82.

18 Vaughan 1991: 82.

19 Saunders 1990: 168-181.

20 Robertson 1999. 


\section{Sir Raphael Cilento and the leprosy raids}

Along with fellow doctors John Cumpston and John Elkington, Sir Raphael Cilento played a key role in the development of quarantine and tropical disease management policies in Australia during the interwar period. Cilento a medical practitioner, published author and career public servant undertook his medical training at the University of Adelaide and later at the London School of Tropical Medicine. ${ }^{21}$ His first major appointment was as Director of the Australian Institute of Tropical Medicine (based in Townsville) in 1922, followed soon after by a secondment to Rabaul to be Director of Public Health for the Mandated Territory of New Guinea (1924-1928). In 1928 he succeeded Elkington as the Commonwealth Health Department's Director of Tropical Hygiene and Chief Quarantine Officer in Brisbane. ${ }^{22}$ It was during his time as Director of Tropical Hygiene that Cilento became more closely involved in Aboriginal health and undertook research into Aboriginal health and leprosy incidence in the North Queensland Aboriginal population. Previously Cilento's work - both bureaucratic and medical - had been primarily focused on tropical medicine, the health of whites living in Australia's Tropical North, and the preventive medical doctrine of national hygiene.

Cilento's interest in leprosy was longstanding, and during his time as Director of Tropical Hygiene and Chief Quarantine Officer for the Commonwealth Health Department (1931-1933) Cilento undertook research into Aboriginal leprosy infections in North Queensland. Most notably he took part in police-assisted leprosy raids in which Aboriginal people suspected of contact with confirmed leprosy sufferers were pursued, detained and subjected to compulsory medical examinations. The majority of the raids took place in 1931 when Cilento, accompanied by local police officers, 'chased up' Aboriginal leprosy contacts in North Queensland. The 'sight of an ambulance', he recalled, was enough 'to send them [Aborigines] scuttling from any camp into the bush' ${ }^{23} \mathrm{He}$ and the police therefore made surprise visits to Aboriginal camps before daybreak to ensure camp residents could not run away and hide. He informed his wife: 'We caught and examined most of those [Aborigines] we wanted but there [we]re several whom the police themselves ha[d] been hunting for months and they got away'. One Aboriginal woman 'Polly' who escaped capture, Cilento was annoyed to later learn, had been 'sitting in the bush with her hands over her two kids mouths' fearful of what the whites were planning to do to her and her children. ${ }^{24}$ Although Cilento expressed no empathy for Polly and her frightened children, one captured Aboriginal man described by Cilento as 'a young and powerful aboriginal' whose 'tell tale heart fluttered the skin like a captive bird',

21 Cilento 1920, 1925, 1944; Cilento and Lack 1959.

22 Yarwood 1991: 49-51. See also Finnane 2007: 215-216.

23 Aboriginal people typically deserted their homes at the first sign or rumour that whites, especially white police officers, were approaching, as they were understandably fearful of being removed to an Aboriginal reserve. Watson 1993: 78; Watson 1989: 4. See also Rosser 1985: 104.

24 Raphael Cilento to Phyllis Cilento, 25 September 1931, Diary letters, UQFL44, Box 11, Folder 44/21, Fryer Library, University of Queensland [hereafter FL]. 
inspired a measure of empathy in the doctor. He wrote: 'I felt a curious little pang of pity and remorse just as I have always felt when I have seen natives charge into rifle fire or some other hopeless [act].' ${ }^{25}$

In many ways the Cilento-led leprosy raids re-articulated the existing policies of the Queensland Chief Protector of Aboriginals' Office, which focused on the capture and removal of 'troublesome' Aborigines to government institutions such as Cherbourg and Palm Island. ${ }^{26}$ Cilento, like the police officers who accompanied him, were representatives of colonial authority and their actions (the surprise visits, forced medical examinations and removals), inspired no trust in the local Aboriginal people but rather were a source of constant fear. Moreover the leprosy patrols epitomised the close connection between the policing of race and health in interwar Australia and the 'pathologising' of Aboriginal sociality as a public health threat. ${ }^{27}$ Cilento argued the 'native habits of changing their names repeatedly further disguises relationships already masked by the haphazard use of the terms "brother", "father", "cousin", "uncle", etc. [and] renders it utterly impossible to contemplate any system other than segregation' for the Aboriginal population. $^{28}$

The North Queensland leprosy round-ups of 1931 paralleled those conducted by the Western Australian government in the North Kimberley region between 1934 and 1945. The Kimberley leprosy patrols, known colloquially as the 'big round up', typically consisted of a white police officer assisted by two or three Aboriginal trackers, occasionally accompanied by a white medical officer. The Western Australian leprosy campaign, Mary Ann Jebb observes, was conducted in a way that reinforced the pre-existing pattern of police raids on Aboriginal people rather than attempting to introduce medical practices as 'a form of government assistance and protection for Aboriginal people' ${ }^{29}$ In both Western Australia and Queensland the methods used during leprosy raids were similar to those used to capture criminals. A typical Western Australian leprosy raid, Jebb describes, involved the police officers surrounding an Aboriginal camp and at dawn, raiding the camp, firing shots in the air or at dogs to stop people fleeing, and all leprosy suspects were placed in chains. Accounts of the Kimberley raids are nearly identical to Cilento's description of his North Queensland experiences. ${ }^{30}$

However, the Kimberley patrols, unlike those of Queensland, came about because of economic and political considerations and were fully endorsed by the government. For example in northern Western Australia white station people took the drastic measure of sending their families away from the area

25 Raphael Cilento to Phyllis Cilento, 25 September 1931, Diary letters, UQFL44, Box 11, Folder 44/21, FL.

26 Watson 1993; Kidd 1994; Reynolds and May 1995: 168-207.

27 Bashford and Nugent 2002: 114.

28 Cilento, Series 1928/1, Control 690/8/106, Barcode 143806, National Archives of Australia [hereafter NAA].

29 Jebb 2002: 137.

30 Jebb 2002: 139. 
and threatening to abandon their pastoral leases if the government did not take action to control the Aboriginal leprosy problem. ${ }^{31}$ No similar action occurred in Queensland, despite public concern about Aboriginal leprosy cases. The Western Australian leprosy campaign therefore had an economic dimension notably absent from the Queensland context, which focused primarily on the medical impacts of leprosy. In accordance with economic considerations the Kimberley leprosy patrols focused on those Aboriginal people who were not part of the pastoral industry's workforce and who moved around the bushlands of the northern ranges of the Kimberley. The Western Australian leprosy campaign, Jebb argues, placed considerable pressure on bush Aborigines 'to settle down with a pastoral manager and conform to station life' ${ }^{32}$

The North Queensland leprosy round ups were different in that they were not officially sanctioned by either the Queensland State or Commonwealth governments. Cilento acknowledged in a letter to his wife: 'Everything I did was unauthorised, most of it illegal and it went along a song' ${ }^{33}$ The unofficial nature of the raids ensured they were a short-lived phenomenon. Cilento only records engaging in such raids during 1931, although he made another research trip to North Queensland in 1932. ${ }^{34}$ Moreover Cilento's focus quickly shifted from the identification of Aboriginal 'lepers' to their policing, and from 1933 he began to campaign for the creation of a separate Aboriginal-only leprosarium in North Queensland. In 1933 he wrote an article in the International Journal of Leprosy in which he suggested an area be set aside for an Aboriginal 'leprosarium and village community', which would house, 'not only bacteriologically positive cases ... but [also] where suspects [could] be kept in confinement and dealt with more satisfactorily' ${ }^{35}$

A vigorous public debate about the diagnosis, treatment and control of leprosy occurred in Queensland during the late nineteenth and early twentieth centuries, with considerable opposition to the spatial isolation of white leprosy sufferers. However by the 1930s medical segregation was the accepted method of leprosy management in the state. ${ }^{36}$ The racial imperatives of leprosy control, rather than diminishing as the twentieth century progressed, actually intensified in the interwar period as reflected in the works of doctors Sir Raphael Cilento and Cecil Cook. ${ }^{37}$ Cook's leprosy studies in the 1920s positioned leprosy as a type of sexual transmitted infection caused by 'racial mixing' between white men and Aboriginal women and tied in with his concern about the regulation of miscegenation. ${ }^{38}$ In contrast Cilento emphasised racial susceptibility, negative

31 Jebb 2002: 153.

32 Jebb 2002: 136.

33 Raphael Cilento to Phyllis Cilento, 25 September 1931, Diary letters, UQFL44, Box 11, Folder 44/21, FL.

34 Cilento, Series 1928/1, Control 4/5, Section 1, Barcode 141738, NAA.

35 Cilento 1933: 50.

36 Robertson 1999: 161-201.

37 Cook was later Chief Protector of Aborigines and Chief Medical Officer. Cook 1924, 1926; Bashford 2003; Parry 2003.

38 For analysis of Cook's work see Anderson 2002; Bashford 2003; Parry 2003. 
impacts of colonialism and poor nutrition as possible explanations for the high incidence of leprosy amongst the Aboriginal population. Despite their difference of opinion, the work of both doctors highlights the extent to which concerns about leprosy contagion intersected with societal fears about racial intermingling during this period. Robertson argues that it was precisely because leprosy refused to remain the disease of 'others' (other races or classes) that it became 'increasingly important to maintain racial distinctions' ${ }^{39}$ Moreover in the specific context of Australia's tropical north, anxieties about the degeneration of the white race in tropical environments heightened existing unease about how best to control diseased and raced bodies. ${ }^{40}$

In the Queensland context it was the work of Cilento, rather than that of Cook, which shaped Queensland government leprosy controls during the 1930s and 1940s in his role as the state's Director-General of Health and Medical Services. Cilento was an avid supporter of the medical segregation of all leprosy patients irrespective of race. However he was particularly committed to the spatial isolation of Aboriginal leprosy patients and argued that ' $[\mathrm{t}]$ heir complete dread of white society's medicine' made normal surgical and hospital techniques 'utterly impossible'. ${ }^{41}$ The only acceptable solution, Cilento maintained, was the 'complete segregation of all Aborigines diagnosed with leprosy'. ${ }^{42}$ Although patients on Peel Island lazaret were kept strictly segregated (white from nonwhite) Cilento declared these arrangements insufficient. Informed by 'doomed race' theories Cilento argued that a sole-Aboriginal leprosarium was the 'best possible measure that could be introduced at the present time to safeguard the native population and to meet the present threat of their extinction' ${ }^{43}$

In accordance with his firm beliefs about racial segregation, Cilento made frequent references to the supposedly inherent racial differences between white and Aboriginal leprosy patients in his scientific publications and government reports of the 1930s. ${ }^{44}$ In his opinion Aboriginal leprosy patients were more difficult to treat, displayed notably immoral attitudes and behaviour, and relapsed more frequently than white patients. ${ }^{45}$ Although he did not directly criticise the multiracial status of Peel Island lazaret, he nonetheless began to campaign for the creation of an Aboriginal-only lazaret in the state during the early 1930s. ${ }^{46}$ Even prior to receiving official approval for the Fantome Island leprosarium, Cilento already envisaged Peel Island leprosarium as a white-only institution. In 1938 he informed white staff members of their special responsibilities to white leprosy patients. He instructed them to make white patients feel 'as comfortable as

39 Robertson 1999: 175; Saunders 1989.

40 Anderson 2006, 1996; Bashford 2000: 248-271.

41 Cilento, Series A 1928/1, Item 690/8/106, NAA: 1-4.

42 Cilento, Series A 1928/1, Item 690/8/106, NAA: 1-4.

43 Cilento to Under Secretary, 27 October 1938, Series 4356, Item 717182, QSA; Also see Series 4356, Items $717218,717219,717220$.

44 Cilento to Under Secretary, 27 October 1938, Series 4356, Item 717182, QSA; Cilento, Series A 1928/1, Item 690/8/106, NAA: 1-4.

45 Cilento 1939: 207-208.

46 Cilento 1933: 50. 
possible' and authorised staff to purchase any additional 'luxuries' requested by white patients. ${ }^{47}$ Cilento recommended that patients' relatives be encouraged to make frequent visits to the leprosarium in an effort to discourage 'hopelessness' among patients. ${ }^{48}$ In contrast he made no directives concerning the welfare of coloured patients. Instead he was firmly committed to their removal from the island and the establishment of an Aboriginal-only leprosarium on a remote North Queensland island. His plan eventually came into effect in January 1940 when Peel Island's Aboriginal patients were transported via boat to the newly established Fantome Island leprosarium.

The work of Cook and Cilento, as well as the changing demographic composition of Peel Island lazaret, contributed to the re-conceptualisation of leprosy as an Aboriginal disease during the interwar period. However it is important to note that the significance of this disease construction was primarily confined to the political, scientific and bureaucratic spheres of white society, and the Queensland public did not appear overly concerned about the Aboriginal leprosy threat. This contrasted with the Queensland public's heightened reaction to the threat of Chinese leprosy in the late nineteenth century. In the mid-twentieth century, however, most white Queenslanders felt sufficiently secure in their health and their communities continuing to employ Aboriginal workers on their farms and in their homes despite the apparently new threat of Aboriginal leprosy. ${ }^{49}$ Rather it was Queensland's government officials, specifically Cilento but also the Minister of Health and Home Affairs (EM Hanlon) and Cilento's successor as Director-General (Abraham Fryberg), who were pivotal in the creation of Aboriginal leprosy as a concern within state policy, a threat which in turn justified the government's decision to further remove and constrain Aboriginal leprosy sufferers away from white society. These same officials were willing to concede in the post-war period (albeit with some reservations) that white leprosy sufferers did not require total isolation.

Following his appointment as Queensland's Director-General of Health and Medical Services, Cilento began to further develop his plans for the establishment of an Aboriginal leprosarium. ${ }^{50}$ He personally selected the Palm Islands group as the locality for the new leprosarium. The chosen location at the northern tip of Fantome Island, six hours by boat from Townsville, was a suitably remote location for such a medical institution. Another Aboriginal-only medical segregation facility - Fantome Island Lock Hospital- operated at the other end of the island (1928-1945) and the state's largest Aboriginal reserve - Palm Island Aboriginal Settlement - was located on a neighbouring island. The government's decision to expand Fantome Island's functions from an Aboriginal lock hospital for Aboriginal 'venereal disease' sufferers to include an Aboriginal leprosarium

47 Director General to Under Secretary, 19 July 1938, Series 8400, Item 279841, QSA; Cilento 1939: 207-208.

48 Cilento, 'Visit to Peel Island Leprosarium', 31 August 1931, Diary letters, UQFL44, Box 11, Folder 44/21, FL.

49 Moreover both the Queensland media and state parliamentarians were notably silent on the matter of Aboriginal leprosy, which indicates the issue was not considered especially important to the general public.

50 Cilento to Walker, 21 February 1935, Correspondence, UQFL/44, Box 4, Folder 11, FL. 
came about through the concerted efforts of Cilento throughout the 1930s, which culminated in the Commonwealth government, through the auspices of its research funding organisation National Health and Medical Research Council, agreeing to fund the establishment of Fantome Island leprosarium. ${ }^{51}$

\section{A problematic beginning - the establishment of Fantome Island leprosarium}

The leprosarium officially opened on 10 January 1940, with the arrival of Aboriginal patients transported from Peel Island lazaret. ${ }^{52}$ Matron Avonia O'Brien, the senior nurse on Peel Island, accompanied the 49 Peel Island patients on their journey to Fantome Island and stayed on until the arrival of the Sisters of Our Lady Help of Christians (OLHC) in March 1940. ${ }^{53}$ Additional white staff consisted of FH Julian, long serving white administrator of Fantome Island lock hospital, who served as Superintendent of both the leprosarium and the lock hospital, and Dr Courtney, Palm Island's Medical Officer, who was appointed visiting Medical Officer of the new institution. The leprosarium's patient population steadily increased during the first six months of 1940 and by July totalled 74 patients (41 men and 33 women).

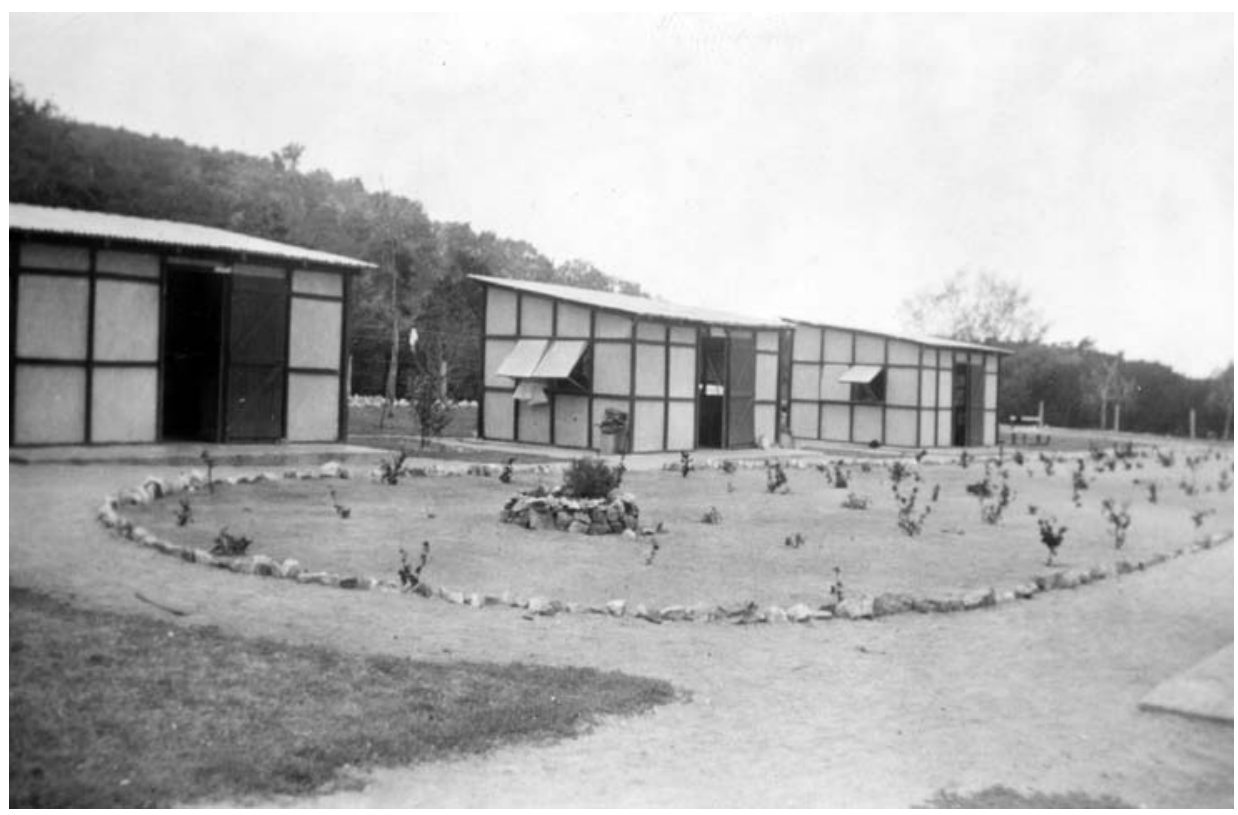

Fig 1. Newly established Fantome Island leprosarium looking north showing one section of patient housing, which was segregated by gender.

Source: Courtesy of Queensland State Archives, ID 279841.

51 The term lock hospital refers to an institution for the spatial segregation of venereal disease sufferers. Parsons 2009. See also Fisher 1994: 67-82; Kidd 1994.

52 'Annual Report of the Director-General of Health and Medical Services 1940-41', Queensland Parliamentary Papers, 2, 1941: 939.

53 Fantome Island Collection, Box D.2, Franciscan Missionaries of Mary Archives [hereafter FMM Archives]; Hammond, 'Relic of lepers' suffering', Courier Mail, 23 September 1985: 9. 
From its inception, the Department of Public Health played a minor role in the day-to-day administration of Fantome Island leprosarium. In addition, and in marked contrast to his earlier involvement, Cilento played a limited role in the operations of Fantome Island leprosarium following its opening in 1940, and made no official visits to the institution. Instead the institution was unofficially managed by the Catholic Church, and Department of Native Affairs; an administrative decision primarily designed to reduce government expenditure on the institution. The Sisters of OLHC initially staffed the leprosarium, but were replaced in 1945 by the larger international order the Franciscan Missionaries of Mary (FMM) who remained at the institution until its closure in 1973. ${ }^{54}$ Additional personnel and medical supervision was provided by officials from the Department of Native Affairs stationed on nearby Palm Island. This shift in responsibility from the administrative domain of medicine to that of mission and reserve resulted in Fantome Island leprosarium being markedly different from its institutional predecessor Peel Island lazaret.

The four OLHC Sisters arrived on Fantome Island two months after the official opening of the leprosarium (see Fig 2). ${ }^{55}$ There they encountered a totally incomplete institution; buildings were unfinished, medical supplies non-existent, and patient food provisions inadequate. ${ }^{56}$ During her time on Fantome, Matron O'Brien repeatedly complained to officials about the poor quality and quantity of food supplied to patients, the substandard accommodation and the general administration of the leprosarium. She 'emphatically state[d]' that the patients were 'given supplies far below the regulations for daily rations' and were suffering ill effects because of the inadequate diet. ${ }^{57}$ The former Peel Island patients, $\mathrm{O}^{\prime}$ Brien remarked, were 'all losing weight' and 'would die' if 'they were not better fed'. ${ }^{8}$ Despite O'Brien's extensive experience on Peel Island, the leprosarium's newly appointed government officials - Superintendent Julian, his assistant Mahony and Dr Courtney - rejected her complaints about food supplies as 'pure fantasy' and evidence of an 'overwrought nervous system'. ${ }^{59}$

54 See Ann Mahony, Sydney, 1995, Fantome Island Collection, Oral History, FMM Archives.

55 Carey 1998: 251-267.

56 See 'Sister Monica Connolly: Memoir', pp. 1-3, Fantome Island Collection, Box D.2, FMM Archives.

57 'Sister Monica Connolly: Memoir', Fantome Island Collection, Box D.2, FMM Archives; O'Brien to Secretary, Department of Public Health, 6 April 1940, Series 8400, Item 279841, QSA.

58 O'Brien to EM Hanlon, Minister of Health and Home Affairs, 12 March 1940, and O'Brien to O'Shea, Secretary of Public Health, 21 January 1940, Series 8400, Item 279841, QSA.

59 Dr CA Courtney to Director of Native Affairs, 26 January 1940, Series 8400, Item 279841, QSA. 


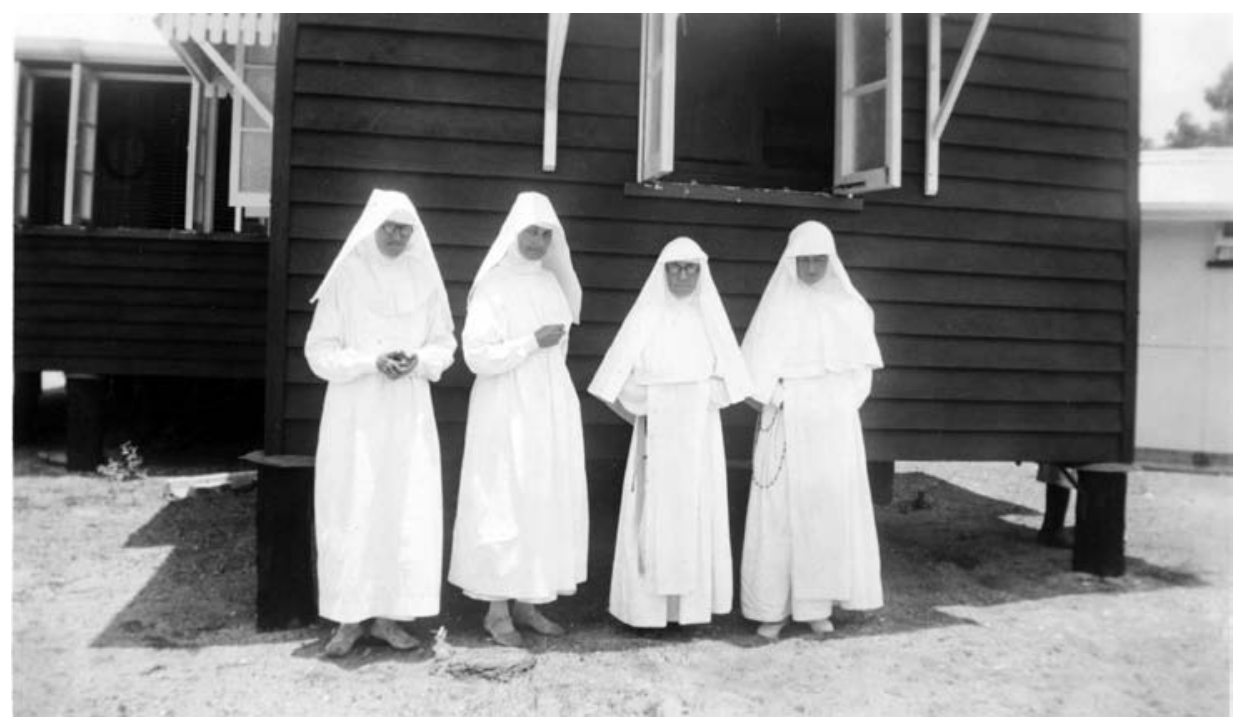

Fig 2. The OLHC Sisters outside their newly erected accommodation, 1940 (from left to right Sister Catherine, Mother Peter, Sisters Agnes and Bernadette).

Source: Courtesy of Queensland State Archives, ID 27984129.

O'Brien's concerns were legitimate and reflected the serious underfunding of the institution. Whereas the Queensland government spent approximately $£ 1000$ per annum on each white patient housed at Peel Island lazaret, the government allocated only $£ 100$ per Aboriginal patient housed at Fantome Island leprosarium (roughly one-tenth the amount spent on Peel Islanders). ${ }^{60}$ Superintendent Julian argued that the rations supplied to patients were adequate and paralleled those received by Fantome Island's lock hospital patients. He maintained it was 'cost prohibitive' to purchase fruit and green vegetables for patients. Moreover Peel Island lazaret administrators, he argued, made 'unnecessary expenditure' on their patients and he would not make the same mistake. Fantome Island's Aboriginal 'lepers' were not, according to Julian, entitled to the quality and quantity of food as Peel Island's white leprosy patients. He declared 'while every proper care must be given to the natives, there appears no necessity for supply on the scale at Peel'. ${ }^{61}$

The government also sought to limit its expenditure on patient accommodation. The accommodation was constructed by Aboriginal labourers from neighbouring Palm Island settlement under the supervision of Julian and other government officials. Patients lived in small huts, which were approximately nine by 15 feet in size, and typically housed two to three people. Each consisted of a concrete floor, hardwood frame covered by 'fibro-cement sheeting' and a corrugated iron

60 Watson 1993: 262; Ludlow 1989: 36; 'Correspondence Relating to Staff of Lazarets', 1905-1940, Series 8400, Item 18248, QSA.

61 Superintendent Julian to Dr Courtney, 24 January 1940, Series A/31756, QSA. 
roof. ${ }^{62}$ Photographs taken in 1940 , soon after the leprosarium's opening, show neat and tidy patient accommodation reminiscent of the native cottages on Palm Island settlement. However the huts were poorly designed and made from cheap, flimsy materials that quickly deteriorated in the tropical climate. After only ten years' use Dr DW Johnson recommended that all buildings at the leprosarium 'be gradually replaced by buildings of more suitable design and construction'. ${ }^{63}$

In 1950 the Director of Native Affairs Cornelius O'Leary (1942-1963) acknowledged the accommodation on Fantome Island was of substandard quality and was rapidly deteriorating in the tropical climate. He declared that his department had allocated funds to rebuild the leprosarium, however 'no competent labour could be induced to undertake the work' and he was wary of employing Aboriginal labourers. ${ }^{64}$ Rather than acknowledging the government's culpability for the leprosarium's inadequate patient accommodation (namely the faulty designs and inappropriate building materials used by his department) $\mathrm{O}^{\prime}$ Leary chose to blame the Aboriginal labourers who constructed the buildings. ${ }^{65}$ Similarly another government official remarked that the 'bad repair' of some huts was 'no doubt, aided by a certain amount of careless use by the patients'. ${ }^{66}$ In 1953 Peel Island's Medical Superintendent Dr Gabriel observed that the housing on Fantome Island was 'far superior' to that provided to Aboriginal inmates on neighbouring Palm Island, an indication of the terrible living conditions Palm Islanders were forced to endure. ${ }^{67}$ The government made no effort to improve accommodation on either Fantome or Palm Islands despite ongoing criticism.

Not surprisingly, the institution's mortality was high during its first decade in operation. In its first year the leprosarium recorded a mortality rate of 20 per cent (202 per thousand). Although a slight decline was recorded in subsequent years, the leprosarium's death rate remained over 10 per cent (100 per thousand) throughout the 1940s. ${ }^{68}$ Of the 49 Peel Island patients who arrived at the leprosarium in January 1940, the majority died within five years of arriving at Fantome Island, not from leprosy, but from tuberculosis. Tuberculosis (TB), a disease associated with overcrowding, poor living

62 'MH Gabriel, Acting Medical Superintendent Peel Island, Report on Visit to Fantome Island April 1953', 8 May 1953, Series 505, Item 505017, QSA.

63 'DW Johnson Report on Lazaret, Fantome Island', 14 July 1950, Series 505, Item 504998, QSA.

64 Director of Native Affairs to Under Secretary, Department of Health and Home Affairs, 11 April 1950, Series 505, Item 505023, QSA.

65 Director of Native Affairs to Under Secretary, Department of Health and Home Affairs, 11 April 1950, SRS 505, 3A/157, Box 464, QSA.

66 'MH Gabriel, Acting Medical Superintendent Peel Island, Report on Visit to Fantome Island April 1953', 8 May 1953, Series 505, Item 505017, QSA.

67 'MH Gabriel, Acting Medical Superintendent Peel Island, Report on Visit to Fantome Island April 1953', 8 May 1953, Series 505, Item 505017, QSA.

68 'Index: Patient names and death dates', Fantome Island Collection, Box D.2, FMM Archives. 
conditions, and nutritional deficiencies, was prevalent at the institution throughout the 1940s, with the overcrowded patient accommodation facilitating the spread of the disease. ${ }^{69}$

\section{Discipline and control}

The Sisters of Fantome Island sought to establish their leprosarium as a therapeutic space, a place of both physical and spiritual reform, where Catholicism was the guiding principle. In many ways the lives of Fantome Island's leprosy sufferers paralleled the lives of Filipino leprosy sufferers on Culion Island several decades prior. Warwick Anderson maintains that the Culion leprosarium, operated by the American colonial government, was a 'laboratory of therapeutics and citizenship' where 'the production of the individual civic subject' served as a form of modern evangelism based on the 'gospel of hygiene' and the wider process of medicalisation. ${ }^{70}$ However on Fantome Island the doctrines of modern medicine, hygienic reform, and Christianity fused to create a space that was simultaneously a Catholic mission, an up-to-date medical institution, and a government-run Aboriginal reserve.

Under the Department of Public Health's administration, Peel Island's Aboriginal and other 'coloured' leprosy patients frequently wrote letters of complaint to government officials and had their complaints investigated. ${ }^{71}$ In contrast, Fantome Island's Aboriginal lock hospital and leprosarium patients were largely unable to protest their confinement through the avenue of letter writing, with Department of Native Affairs staff censuring and restricting patient mail, and disciplining complainants. In the context of Peel Island lazaret, Bashford and Nugent suggest that Aboriginal patients' ability to protest their detention and appeal for better living condition was partly tied to the fact that they were housed alongside white leprosy sufferers. ${ }^{72}$ They argue that:

Avenues of complaint, of written protest, the sense of right of access to the highest judicial bodies, seems to have been more possible from the subject position of 'leper' than from the subject position of 'Aboriginal' or 'half-caste' regulated by the 'normal' systems of race management in interwar Australia, partly because the space and experience of isolation-as-leper was shared with whites. ${ }^{73}$

69 Watson 1993; Bryer, 1988: 97; Ludlow 1989: 39; Watson 1993: 262.

70 Anderson 2006b: 94-99.

71 'Inquiry into Patient Complaints 1908', 18 January 1908, 'Inquiry into certain disturbances at the Lazaret', 19 July 1909, Thomas Moreton to Home Secretary, 13 February 1910, Series 8400, Item 18214, QSA.

72 Bashford and Nugent 2002: 109.

73 Bashford and Nugent 2002: 109. 
In contrast on Fantome Island, I argue and will demonstrate, Aboriginal leprosy patients' status as 'lepers' was a subordinate classification to that of 'Aboriginal', and the avenues of protest, previously available on Peel Island, were unavailable to those on Fantome Island. ${ }^{74}$

Fantome Island leprosy patients were expected to work diligently between their medical treatments as a method to achieve both physical and spiritual healthiness. Unlike on Peel Island where patients did not work, on Fantome Island all patients 'who were fit to work' were required to do so. ${ }^{75}$ Patients 'working minimum hours were unpaid' for their work, although those undertaking 'essential services and special work were paid' a small allowance by the Department of Native Affairs. ${ }^{76}$ Patients performed a range of general labouring, domestic and sanitation tasks around the leprosarium, including cooking and caring for other patients (see Fig 3). The work system was first instituted by Mother Peter, the OLHC mission leader, in 1940, who on arriving on Fantome Island deemed the 'moral state' of patients 'one of idleness' which left 'much to be desired' and declared the entire leprosarium 'very dirty'. ${ }^{77} \mathrm{~A}$ month later Mother Peter was pleased to report a 'marked improvement' in the patients' moral state, brought about because of the allocation of 'duties' to those able to work, which kept 'them busy for the greater part of the mornings' and ensured the leprosarium was gradually 'becoming cleaner'.$^{78}$ However she noted that 'our poor people' were not 'energetic' workers and needed 'constant encouragement' and supervision to ensure they completed tasks and did not 'fall back' into idle ways. ${ }^{79}$ In advocating such a system of supervised work the Sisters were drawing on missionary precepts as well as the standard operating practice of Queensland's various Aboriginal missions and government-run reserves. Work was viewed as a fundamental part of both government and missionary efforts to reform and civilise Aborigines, and can be located within a wider reformative tradition, which included women's reformatories, asylums, prisons, workhouses and industrial schools. ${ }^{80}$

74 Holt 2001; Hegarty 1997; Huggins and Huggins 1994.

75 George Sturges Superintendent, Palm Island Settlement to Deputy Director of Native Affairs, 22 February 1951, Series 505, Item 505020, QSA; Watson 1993: 196.

76 George Sturges Superintendent, Palm Island Settlement to Deputy Director of Native Affairs, 22 February 1951, Series 505, Item 505020, QSA.

77 'Mother Superior: Monthly Report of Fantome Island leprosarium, March 1940', Fantome Island Collection, Box D.2, FMM Archives.

78 'Mother Superior: Monthly Report of Fantome Island leprosarium, April 1940', Fantome Island Collection, Box D.2, FMM Archives.

79 'Mother Superior: Monthly Report of Fantome Island leprosarium, April 1940', 'Mother Superior: Monthly Report of Fantome Island leprosarium, September 1942', Fantome Island Collection, Box D.2, FMM Archives; George Sturges Superintendent, Palm Island Settlement to Deputy Director of Native Affairs, 22 February 1951, Series 505, Item 505020, QSA.

80 Attwood, 2000: 41-54. 


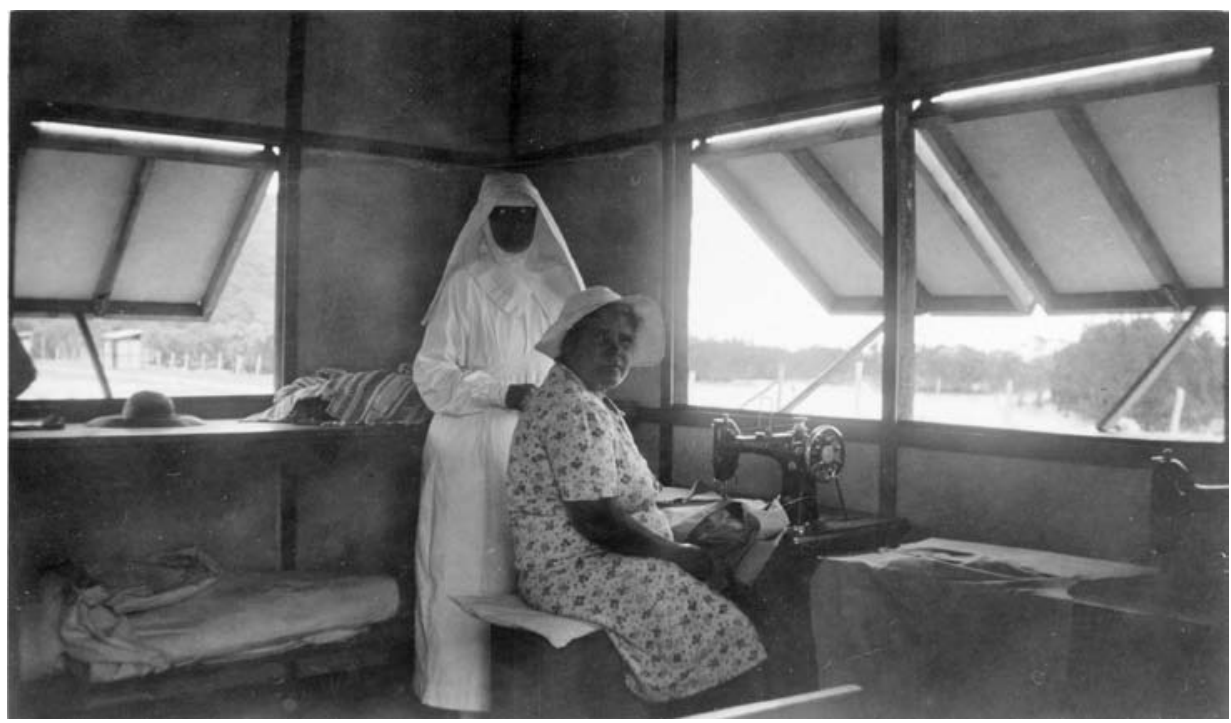

Fig 3. OLHC Sister and leprosarium patient working in the temporary sewing room, circa 1940.

Source: Courtesy of Queensland State Archives, ID 2798419.81

At the Fantome Island leprosarium white officials, like their compatriots on Cherbourg and Palm Island settlements, declared Aboriginal immorality a source of constant concern. The OLHC Sisters affirmed the lack of 'sexual discrimination or separation' between patients as the most pressing issue at the leprosarium, rather than the chronic food shortages or deficient accommodation. ${ }^{82}$ Mother Peter reported her first impressions of Fantome Island leprosarium in a letter to Bishop Ryan:

We find the moral condition of our poor people in a deplorable state. The building accommodation is temporarily inadequate. The sexes are intermixed. There is much to be desired in cleanliness and so on. ... Until this is in order the medical treatment peculiar to leprosy would be of little use. ${ }^{83}$

Officials attempted to rectify this problem by building two separate accommodation compounds, divided by gender and marriage status (see Fig 1). Single females lived in the female compound, while married women lived with their husbands in the male compound, which also accommodated single men. However in the absence of physical barriers and strict policing to keep the sexes apart, as in the dormitories of Cherbourg settlement, Fantome Island's patients were largely free to interact with members of the opposite sex. One FMM Sister

81 This photograph and all others in this article can be found in the records of the Queensland Department of Aboriginal and Torres Strait Islander People held at the Queensland State Archives. Due to the department's access requirements, I cannot name the patient in the photograph.

82 'Sister Monica Connolly: Memoir', Fantome Island Collection, Box D.2, FMM Archives.

83 Sister M Peter to Bishop H Ryan, 6 March 1940, cited by Maguire 1991: 142. 
wrote in dismay after only six months on Fantome Island in 1945: 'Immorality reigns at the leprosarium. It is like a wound, an evil which we try to remedy. ${ }^{\prime 4}$ Similarly Cilento noted that 'immorality' (pre-marital sexual relations) was widespread on Fantome Island and 'admit[ted] that it is very difficult indeed to prevent intercourse between the natives' ${ }^{85}$ Prior to 1947 Fantome Island leprosy patients were not permitted to marry because of concerns about disease transmission to infants. ${ }^{86}$ However the government reconsidered its policies after persistent campaigning from Catholic and Anglican Church officials. ${ }^{87}$ Cilento concluded that when 'pregnancy results it is better that it should be a legitimate pregnancy than a illegitimate one' ${ }^{88}$

No infants born at the Fantome Island leprosarium were allowed to stay at the institution because of fears of infection. In 1944 Cilento declared that the likelihood of infection made the detention of children 'criminally negligent in every sense' ${ }^{89}$ Thus newborn infants were quickly removed from the leprosarium to the Palm Island settlement and placed in dormitories or with Aboriginal foster parents. When a child was born on Fantome Island a nun would immediately take the infant and place it in basket, and hold the basket aloft so the mother and father could catch a glimpse of their child before it was taken away by boat. No physical contact between parents and children was allowed; as a former patient recalls 'I couldn't touch my child. The boat ... didn't wait for anything. ${ }^{\prime 0}$ However the Sisters endeavoured to work around the restrictions to allow mothers to see their infants. Sister Angela recalled:

There was one woman who came in who was pregnant and had a husband and her husband was allowed to come over and stay at the lock [hospital] ... he was allowed to take the baby home [once it was born]. He brought it [the baby] into the room a couple of times ... but she [the mother] wasn't allowed to touch it. ${ }^{91}$

Similarly in 1949 Dr DW Johnson approved one female patient's request to allow her ten-year-old son (whom she had not seen since birth) to visit the leprosarium. Johnson permitted the boy to 'come to the beach and talk to [his mother] at Christmas and at Easter' because the woman was now 'returning negative smears' ${ }^{92}$ On Fantome Island the removal of babies and children

84 'Histoire des Six Premiers Mois de la Foundation de la Leproserie a l'Ile Fantome', p. 2, 'Sister Madonna: History of Fantome Island', p. 15, Fantome Island Collection, Box D.2, FMM Archives.

85 Cilento to Sister M Peter, 7 October 1944, Series 4356, Item 717238, QSA; Also see Series 4356, Items 717239, 71740, 71741, QSA.

86 Cilento to Acting Superintendent, Fantome Island Lock Hospital and Lazaret, 16 July 1941, Series 505, Item 505021, QSA.

87 'The island of sun and solace', Sydney Morning Herald, 19 February 1977; Townsville Catholic News, 1 December 1954; 'Sister Madonna: History of Fantome Island', p. 28, Fantome Island Collection, Box D.2, FMM Archives.

88 Cilento to Sister M Peter, 7 October 1944, Series 4356, Item 717238, QSA.

89 Cilento to Sister M Peter, 7 October 1944, Series 4356, Item 717238, QSA.

90 'The island of sun and solace', Sydney Morning Herald, 19 February 1977.

91 Sister M Angela, Interviewed by Carey, 7 July 1997, cited by Carey 1998: 258.

92 'DW Johnson Report on Lazaret, Fantome Island', 14 July 1950, Series 505, Item 504998, QSA. 
from their parents paralleled the government's Aboriginal dormitory policies; however, unlike the general Aboriginal child-removal policies, on Fantome Island the primary logic was medical rather than socio-cultural and aimed to protect children from leprosy infection. Another former leprosarium patient recalls travelling to Palm Island at low tide and being allowed to stand at the foot of the jetty and talk to his son (who stood on the jetty above his head). He recounts: '[o]nce I reached out and touched him. People jumped at me from all roads. ${ }^{\prime 93}$

The removal of disease-free children from their leprous parents was the standard procedure at leprosariums both in Australia and worldwide. ${ }^{94}$ For example at the Channel Island leprosarium (Northern Territory) infants were removed from their mothers at birth and sent to dormitory accommodation in Darwin. While children born at Culion Island leprosarium were placed in the institution's nursery until the age of two, after which time they were sent to Manila and placed in an orphanage or with adoptive parents. ${ }^{95}$ However at the Lau si Momo leprosy village, a joint colonial government-mission initiative in the Dutch East Indies, infants and children were allowed to stay with their leprosy infected parents because officials believed that mother's milk improved children's chances of survival. ${ }^{96}$

Like Palm Island's Settlement Matron, the nuns of Fantome Island took it on themselves to attempt to discipline and reform Aboriginal females. The leprosarium hospital was 'occasionally used' by the Sisters 'as a jail for women patients who needed punishment of some kind'. The nuns, patients complained, restrained individual women patients 'who caused trouble in the compound by reason of [their] immorality'. ${ }^{97}$ The Sisters maintained that at times physical restraints were 'necessary for the protection' of the women themselves and 'in the interests of law and order [at] the institution'. Although the female patients who suffered this punishment condemned the nuns' behaviour, Dr Gabriel (Peel Island's Medical Superintendent) considered 'the action of the nuns ... reasonable' and argued the 'nuns were very lenient with the patients' ${ }^{98}$ At Fantome Island leprosarium the physical control of those women deemed 'immoral' suggests that the Sisters were attempting to inculcate modesty and abstinence in Aboriginal females by emphasising ideas of sin and guilt, especially in regards to sexual matters. Bain Attwood has similarly observed that on Ramahyuck, an Aboriginal mission station established by Moravian

93 Herbert Paddy Tanna recounted being separated from his son while a patient at Fantome Island to journalist Alan Gill. See 'The island of sun and solace', Sydney Morning Herald, 19 February 1977.

94 Saunders 1989; Anderson 2006b: 94.

95 Anderson 2006b: 94-115.

96 Kipp 1994: 172.

97 'MH Gabriel, Acting Medical Superintendent Peel Island, Report on Visit to Fantome Island April 1953', 8 May 1953, Series 505, Item 505020, QSA; also see Series 505, Item 505021.

98 'MH Gabriel, Acting Medical Superintendent Peel Island, Report on Visit to Fantome Island April 1953', 8 May 1953, Series 505, Item 505020, QSA. 
missionaries in eastern Victoria in 1863, missionaries attempted to transform the 'nature of Aboriginal control of their bodily selves' through Christian teachings, which aligned sex with sin. ${ }^{99}$

Along with the nuns' use of the hospital as a female detention ward, other disciplinary measures were implemented on Fantome Island during the mid1940s. A native police force was employed from 1946 under the direction of Palm Island's Superintendent GR Roberts. ${ }^{100}$ In addition two gaol cells were constructed on the island, 'one for female and the other for male offenders'. Roberts argued that the presence of a gaol at the leprosarium would have a 'beneficial influence on the discipline of the patients'. At the present time, he reasoned, there was 'no special place for the incarceration of natives guilty of an offence' and thus there was 'no means [to] dete[r] offenders or in the case of a serious crime, no special place in which to hold them in custody'. ${ }^{101} \mathrm{O}^{\prime}$ Leary, Director of Native Affairs, agreed with Roberts' penal proposal and 'strongly recommend[ed] the construction of concrete or strong wooded cell[s]' at the leprosarium. O'Leary maintained that the cells could be used for a range of purposes including the detention of 'one male patient' at the facility who was, he stated, 'slightly mental' and 'may have to be detained should his conduct deter[ior]ate.' ${ }^{102}$ The leprosarium's gaol cells, native police force, and hospital/ detention ward indicate the crossover of medical and punitive rationales. ${ }^{103}$ In many ways the implementation of punitive measures at the leprosarium is unsurprising considering that nearby Palm Island was an Aboriginal penal settlement and that harsh disciplinary measures had previously been used by lock hospital staff. However, the harsh disciplinary practices contrasted with the Sisters' generally up to date and humane medical treatment of patients.

\section{Medical and nursing care}

The leprosarium was equipped with a six-roomed hospital building (see Figs 4 and 5), which contained a doctor's room, laboratory, dispensary, dental unit, verandah, hospital ward, and adjoining kitchen (located in a separate building). While the hospital housed the OLHC Sisters temporarily, the patients were treated outside or in their huts. Two dressing stations, where Sisters dressed patients' wounds, were located in each of the patient compounds. Each dressing station was also provided with a small dispensary that contained frequently used drugs, in particular chaulmoogra oil. ${ }^{104}$ OLHC Sister Catherine recalls:

99 Attwood 2000: 50.

100 GR Roberts, Acting Superintendent Palm Island, to Director of Native Affairs, 20 February 1946, Series 505, Item 505023, QSA.

101 GR Roberts, Acting Superintendent Palm Island, to Director of Native Affairs, 20 February 1946, Series 505, Item 505023, QSA.

102 GR Roberts, Acting Superintendent Palm Island, to Director of Native Affairs, 20 February 1946, Series 505, Item 505023, QSA.

103 Finnane and McGuire 2001: 279-298.

104 'MH Gabriel, Acting Medical Superintendent Peel Island, Report on Visit to Fantome Island - April 1953', 8 May 1953, Series 505, Item 505023, QSA; 'Monthly Reports on the operation of Fantome Island leprosarium', 1940-1944, Fantome Island Collection, Box D.2, FMM Archives. 
Each day the patients' sores were cleansed and dressed. In bad cases, they had to be done twice daily. Medicine was given for leprosy and also for any other complaint the patient might have. ${ }^{105}$

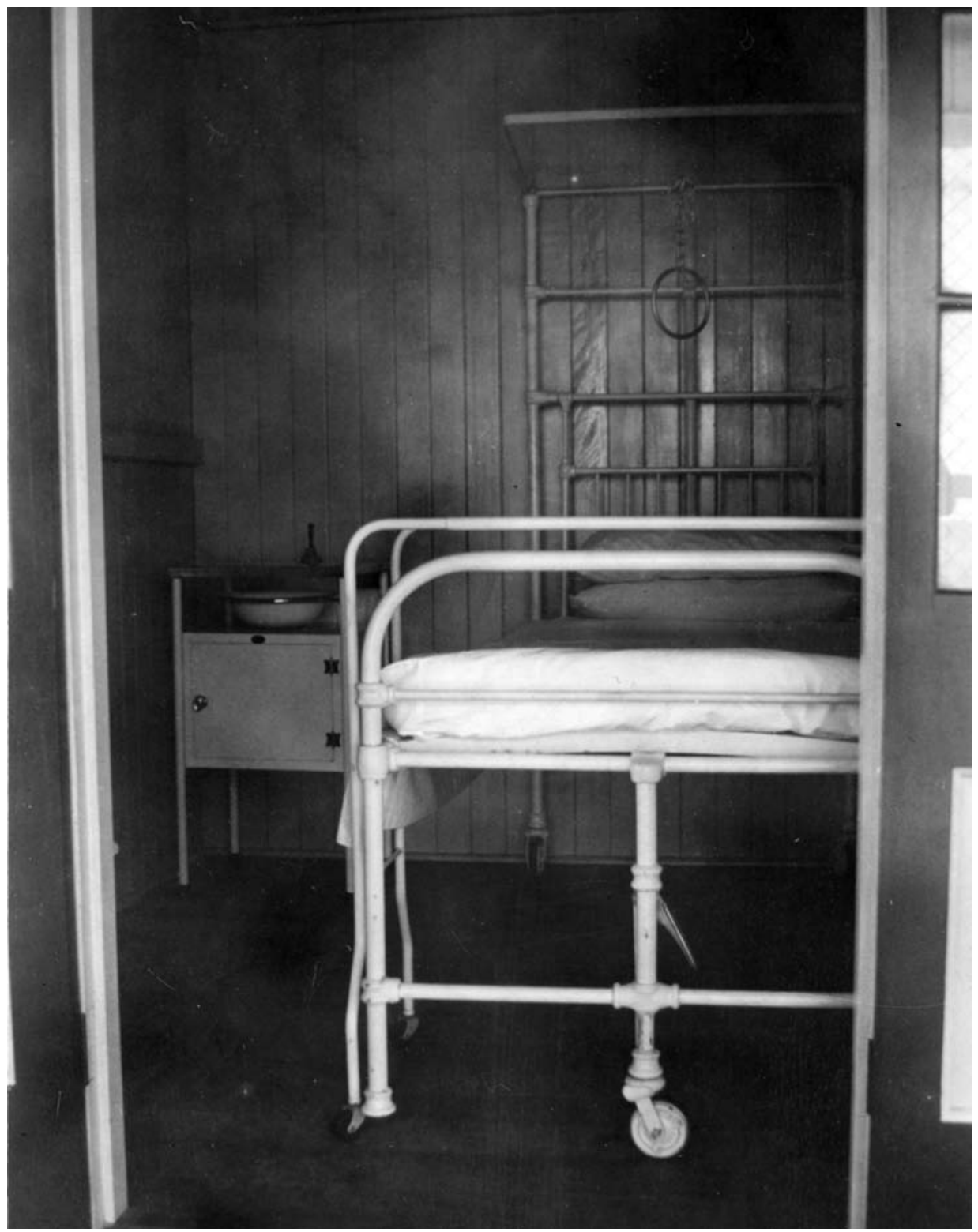

Fig 4. Leprosarium hospital showing in-patient treatment room, 1940.

Source: Courtesy of Queensland State Archives, ID 279841.

105 Ann Mahony, Sydney, 1995, Fantome Island Collection, Oral History, FMM Archives; 'Sister Madonna: History of Fantome Island', p 14, Fantome Island Collection, Box D.2, FMM Archives. 


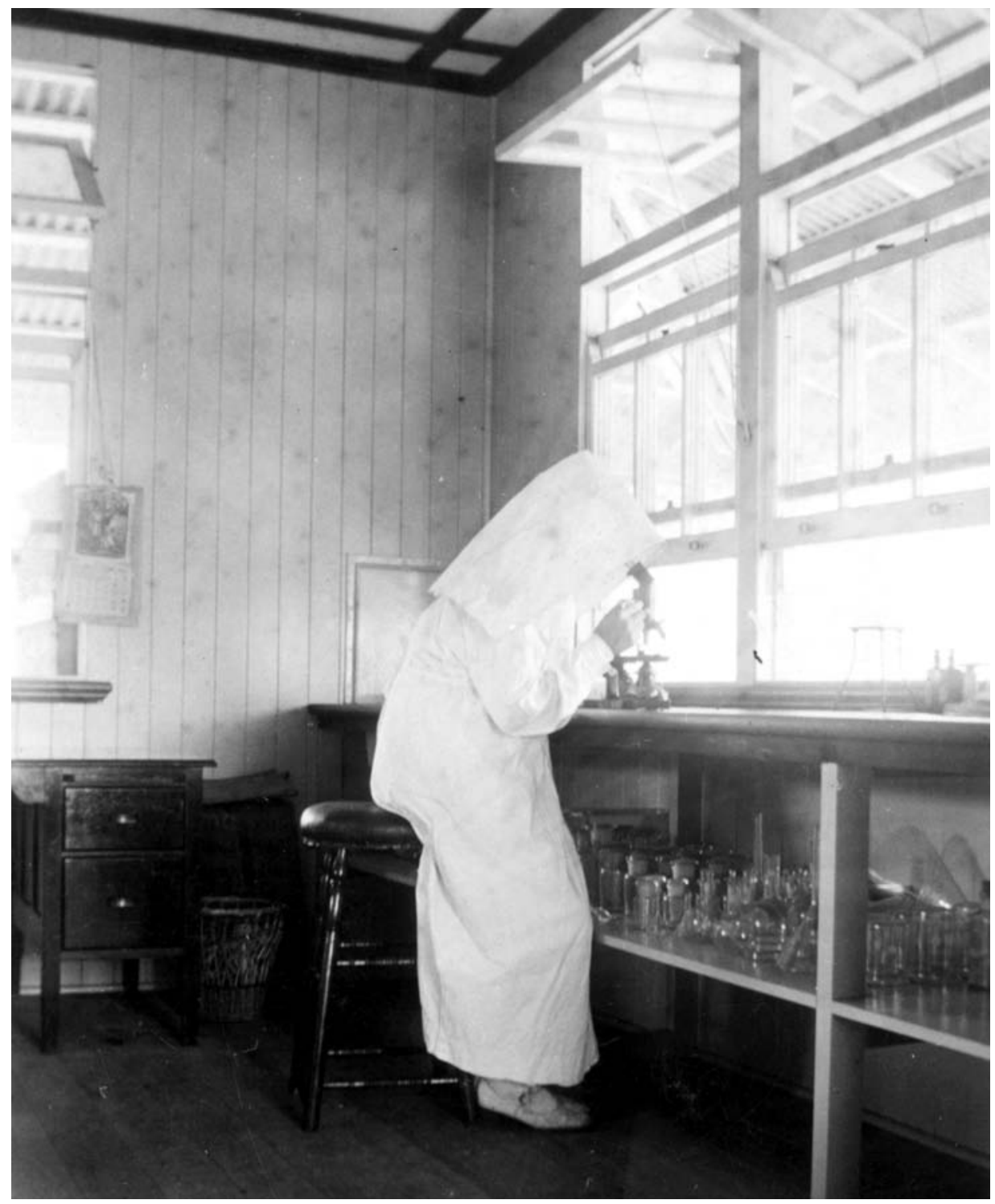

Fig 5. OLHC Sister in the laboratory, 1940.

Source: Courtesy of Queensland State Archives, ID 279841.

Fantome Island's leprosy patients, like those on Peel Island, were required to undergo regular smears to test for the presence of the leprosy bacterium. Aboriginal leprosy suspects detained on Palm Island were also subjected to this regime of monthly smear tests. ${ }^{106}$ Each patient was required to undergo smear testing once a month, which involved blood samples being collected from the

106 Dr Short, Palm Island Medical Officer to Director of Native Affairs, 7 December 1947, Series 505, Item 505317, QSA. 
eyebrow, cheek, ear lobe and nostril. The process of smear collection caused patients considerable discomfort and many patients experienced excessive bleeding. ${ }^{107}$ A leprosy suspect detained at Palm Island Aboriginal Settlement recounts:

The doctor then put an instrument which looked like a needle to me up my left nostril. It hurt me when he put that up my nostril. I threw my head back a little bit when the needle hurt me and cried out with the pain. When I cried out the doctor slapped me across the right cheek with his open hand. It was a hard slap. At the same time he put the instrument further up [my] nostril and this caused it to bleed a lot, some of it got on my dress ... I nearly fainted... ${ }^{108}$

However FMMSisters and the Department of Health and Home Affairs attempted to downplay the pain and discomfort patients endured. After collecting the smears, the Sisters transferred them onto slides, and examined the slides under the microscope in the leprosarium laboratory (see Fig 5). The slides were then sent on to the government laboratory in Brisbane for secondary analysis.

Throughout the 1940s Fantome Island's leprosy patients required 24 consecutive negative smear results (taken at monthly intervals) before they were eligible for discharge to Palm Island settlement, and in the 1950s, following the introduction of sulphone-based drugs, the number was reduced to 12 negative smears. ${ }^{109}$ Similarly on Peel Island leprosarium patient discharge requirements declined due to improved medical treatments in the 1950s. Whereas in 1950 white patients required 12 consecutive negative smears, by 1958 only three negative smears were required before they could be discharged. ${ }^{110}$ However, all discharged patients, white and Aboriginal alike, were obliged to submit to regular medical examinations (including smear tests) for several years after their discharge. ${ }^{111}$

Chaulmoogra oil was the standard treatment for leprosy worldwide and was used on both Peel and Fantome Islands. ${ }^{112}$ On Fantome, the Sisters recorded that many patients suffered severe reactions (including nausea and blindness) to the oil. ${ }^{113}$ In August 1948 the antibiotic Promin was given to Fantome Island's leprosy patients for the first time. Peel Island's patients were treated with the sulphone-

107 'Report of Stipendiary Magistrate AM Taylor, Court House Ayr', 26 June 1944, Series 505, Item 505305, QSA.

108 'Statement of Leprosy Patient', 21 June 1944, Series 505, Item 505312, QSA. In accordance to the requirements of the Department of Aboriginal and Torres Strait Islander Affairs I do not identify any Aboriginal person detailed in the QSA files by name and use a pseudonym where applicable.

109 See entire folder entitled 'Palm Island - Submission of Smears', Series 505, Item 505317, QSA.

110 Under Secretary, Department of Health and Home Affairs, to Director of Native Affairs, 5 September 1958, Series 4356, Item 717235, QSA.

111 During the 1930s several discharged Aboriginal leprosy patients were sent from Peel Island to Cherbourg settlement, and Cherbourg hospital staff were required to take regular smears from the patients. See the entire folder Series 1890, Item 336204, QSA.

112 Bashford 2003: 91

113 Watson 1993: 264. 
based drug from January 1947. ${ }^{114}$ The new drugs quickly arrested the disease in most patients. ${ }^{115}$ However, like chaulmoogra oil, they also produced reactions including nausea, fever, dizziness and angioedema (swelling). ${ }^{116}$ In 1951 the Department of Native Affairs reported that only ten per cent of Fantome Island leprosy patients were able to receive sulphone treatments 'without any apparent reaction or discomfort', while 90 per cent suffered side effects. Treatment dosages were largely experimental, Director of Native Affairs Cornelius O'Leary explained, and there were few methods available to control these reactions. ${ }^{117}$ Despite the severe reactions many Fantome Island patients seemed to respond to sulphone drugs and during the 1950s patient mortality rates gradually declined, while patient discharge numbers steadily increased. ${ }^{118}$ Between 1950 and 195571 patients were discharged from Fantome, with 19 discharged in 1954 alone; prior to the introduction of sulphone drugs discharges had averaged just one patient per year. ${ }^{119}$

While the Sisters welcomed the introduction of more effective sulphone-based drug treatments from 1948, their enthusiasm for the new drugs was tempered by their concerns about patients' diminishing belief in Christianity. One FMM Sister was alarmed to report that improving health and lowering mortality rates at the leprosarium was having a negative effect on patients' behaviour, most notably diminishing church attendance. ${ }^{120}$ From her perspective this was evidence of moral ill health, comparable to the physical ill health caused by leprosy. From the standpoint of the OLHC and FMM missions, questions of health and morality were inexorably related to religious belief. Moreover the purpose of the Sisters' work was not only to treat patients' physical conditions but also their spiritual needs.

\section{Movement to close Fantome Island}

In the 1950s a dramatic increase in the number of patients eligible for discharge occurred as a result of new drug therapies. However the Department of Native Affairs was reluctant to discharge former leprosy patients to their home districts. Instead the department declared that all former 'lepers' would be sent to Palm Island settlement where they could be appropriately supervised. ${ }^{121}$ The department's decision to send former patients to Palm Island paralleled the

114 'Annual Report of the Director-General of Health and Medical Services, 1949-50', QPP, 2 (1950): 19.

115 Johansen 1951: 445-446; 'Annual Report of the Director-General of Health and Medical Services, 1949-50', QPP, 2 (1950): 19; Patrick 1987: 64; Mom 1948: 85-86.

116 Ludlow 1989: 104; 'Annual Report of the Director-General of Health and Medical Services, 1949-50', QPP, 2 (1950): 19.

117 'Annual Report of the Department of Native Affairs for the Year ending 31st December 1950', QPP, 2 (1951): 1054.

118 'Index: Patient names and death dates', Fantome Island Collection, Box D.2, FMM Archives.

119 'M Chrysanthe: Provincial Journal, 22 August 1953', 'Index: Patient names and death dates', Fantome Island Collection, Box D.2, FMM Archives.

120 'M Chrysanthe: Provincial Journal, 22 August 1953', 'Index: Patient names and death dates', Fantome Island Collection, Box D.2, FMM Archives. See also Kipp 1994: 165-178. April 1953', 8 May 1953, Series 505, Item 505017, QSA. 
department's treatment of Fantome Island's discharged VD patients a decade earlier, and brings us once again to question the meaning and effect of detention in the context of Fantome Island. Detention on Fantome Island, both at the lock hospital and the leprosarium, was a result of convergent rationales of segregation (punitive, quarantine, therapeutic and racial), with the rationale of racial segregation given primary importance by the Queensland government for most of the twentieth century.

Current medical knowledge and practices were given little consideration by government officials who debated the future of Fantome Island leprosarium during the late 1960s and early 1970s. Dr Gabriel, former Medical Superintendent of Peel Island lazaret, declared that transferring Aboriginal patients to the leprosy ward at Brisbane's Princess Alexandra Hospital would be 'disastrous' because they would cause infinite disciplinary 'problems' and unnerve white patients. ${ }^{122}$ Instead Gabriel called for the establishment of an Aboriginal-only leprosy ward on Palm Island settlement where 'troublesome' Aboriginal leprosy patients could be detained away from the white population; echoing the sentiments of Cilento some 30 years later. The Queensland Cabinet eventually approved the construction of such facility - a six-bed isolation ward - on Palm Island. The new ward was to be funded and managed by the Department of Aboriginal and Islander Affairs (as the Department of Native Affairs was known from 1965) as opposed to the Department of Health. This transfer of control from the Department of Health to the Department of Aboriginal Affairs formalised the already close connection between the government's management of leprosy and its management of Indigenous peoples. ${ }^{123}$

The government's decision encountered widespread opposition from the FMM Sisters, Palm Island settlement staff, Fantome's six remaining leprosy patients and the Medical Superintendent of Townsville Hospital (Dr David Bowler). ${ }^{124}$ Dr Bowler argued that the isolation ward was not in line with current leprosy management procedures which favoured rehabilitative and community treatment options. He observed that leprosy was now primarily 'a social problem, not a medical one', and the government needed to work towards overcoming people's 'emotional and groundless' fears of the disease. ${ }^{125}$ The leprosarium patients, officials reported, expressed genuine alarm at the prospect of being sent to Palm Island where they believed 'they would be locked up and isolated'. ${ }^{126}$ Once again the Queensland government rejected all complaints and

122 Dr Gabriel Memorandum to Director-General of Health and Medical Services, 21 February 1973, Series 505, Item 505023, QSA.

123 Director-General of Health and Medical Services to Reverend Mother, Franciscan Missionaries of Mary, 7 December 1970, 'Report of David P Bowler Medical Superintendent Townsville Hospital into Fantome Island Leprosarium', 18 January 1971, Series 505, Item 505023, QSA.

124 Sister Jermaine Bellmare to Mr Killoran, 25 August 1970, Series 505, Item 505023, QSA.

125 'Report of David P Bowler Medical Superintendent Townsville Hospital into Fantome Island Leprosarium', 18 January 1971, Series 505, Item 505023, QSA.

126 'Report of David P Bowler Medical Superintendent Townsville Hospital into Fantome Island Leprosarium', 18 January 1971, Series 505, Item 505023, QSA. 
noted the financial savings it would make by housing patients on Palm Island. ${ }^{127}$ The six Aboriginal leprosy patients (all male) housed at the specially built isolation ward at Palm Island Hospital, in contrast to the white leprosy patients housed at Princess Alexandra Hospital, were prohibited from interacting with the rest of the Aboriginal reserve population and remained confined to the ward. Evidently the 'politics of race' continued to underwrite the policy and practice of public health in Queensland during the 1970s, with the isolation of Aboriginal leprosy sufferers within an Aboriginal reserve reminiscent of the government's initial response to Aboriginal VD sufferers in the 1910s. ${ }^{128}$

\section{Conclusion}

The decision to remove and detain Aboriginal leprosy patients in an isolation ward on an Aboriginal reserve represents a continuation of the government's longstanding leprosy controls, first introduced by the Queensland government almost a century earlier and reinforced by the work of Cilento and Cook in the interwar period. Although the government modified its leprosy management strategies following the advent of sulphone-based drugs, officials remained unwilling to completely abandon the policy of medical segregation with regards to Aboriginal patients. However, the enforced isolation of Aboriginal leprosy sufferers was the typical rather than exceptional government policy in the specific context of Northern Australia, and Aboriginal-only leprosarium continued to operate in both Western Australia and the Northern Territory until the 1980s. ${ }^{129}$ As Parry has noted, the governments of Northern Australia retained their policies of isolating Aboriginal leprosy patients, despite mounting international and local criticism, for racial rather than medical reasons. ${ }^{130}$ In this way issues of race, as Bashford has previously observed, pervaded the management of leprosy throughout Australia. ${ }^{131}$

Aboriginal leprosy patients, in spite of decreasing infection rates and improvement of treatment outcomes, continued to be depicted and treated by officials as potentially dangerous and as possible sources of contagion. Aboriginal disease, more generally, continued to be framed in problematic terms by medical officials. The framing of disease, as Rosenberg and Golden have argued, dictates how a society will respond to a disease and affects medical knowledge, treatment options, medical care, public policy, and the behaviour of those diagnosed with the disease. ${ }^{132}$ In the context of twentieth-century Queensland, the framing of leprosy as a disease of non-whites ensured that spatial segregation remained the pre-eminent treatment option for much of the century. Even when medical

127 Acting Health Officer to Director-General of Health and Medical Services, 7 September 1973, Series 505, Item 505023, QSA.

128 Stoler 1995: 113.

129 Saunders 1990: 168-181.

130 Parry 2003: 17.

131 Bashford 2003: 91.

132 Rosenberg and Golden 1991: xiii. 
knowledge disproved prior theories about leprosy, including the link between race and disease susceptibility, support for the medical segregation of Aboriginal leprosy sufferers remained largely undiminished. This related to the persistence of white community and governmental support for the racial segregation of Aboriginal and white communities. However, it is important to recognise that Fantome Island leprosarium and the overarching leprosy management policies of the Queensland government did not arise from an uncomplicated or consistent rationale (that is, racial segregation). Rather, as Mark Cherry has shown, particular medical social realities emerged from a range of moral and epistemological assumptions. Medicine, as I have sought to demonstrate, is not a neutral discipline, because to 'describe a human condition, ... as a disease to be treated medically, ... is to advance moral and conceptual judgements that fashion licit and illicit health care practices'. Thus the 'social ontology of morality and medicine' are inextricably intertwined. ${ }^{133}$

\section{References}

\section{Archival Sources}

Franciscan Missionaries of Mary Archives, Sydney

Fantome Island Collection, Box D.2.

Fantome Island Collection, Oral History.

Fryer Library, University of Queensland, Brisbane

Cilento, Raphael, Sir, Papers 1913-[198-], UQFL44, Box 11, Folder 44/21.

Cilento, Raphael, Sir, Papers 1913-[198-], UQFL/44, Box 4, Folder 11.

National Archives of Australia

Series 1928/1, Control 4/5, Section 1, Barcode 141738.

Series 1928/1, Control 690/8/106, Barcode 143806.

Queensland Parliamentary Papers

Queensland Parliamentary Papers, 2, 1941, 1950, 1951.

Queensland State Archives

Correspondence Files: Chief Protector of Aboriginals' Office

133 Cherry 1996: 357. 
ABORIGINAL HISTORY 2010 VOL 34

Series 505, Item 504998

Series 505, Item 505017

Series 505, Item 505020

Series 505, Item 505021

Series 505, Item 505022

Series 505, Item 505023

Series 505, Item 505305

Series 505, Item 505317

Series 505, Item 505325

Series 18090, Item 336204

Department of Health and Home Affairs

Series 4356, Item 717218

Series 4356, Item 717219

Series 4356, Item 717220

Series 4356, Item 717221

Series 4356, Item 717238

Series 4356, Item 717239

Series 4356, Item 717240

Series 4356, Item 717241

Special Batches: Colonial Secretary's Office

Series 8400, Item 279841

Series 8400, Item 18214

Series 8400, Item 18248

Newspapers

Progress

The Townsville Catholic News 
The Worker

\section{Secondary sources}

Anderson, Warwick 1996, 'Immunities of empire: race, disease and the new tropical medicine, 1900-1920', Bulletin of the History of Medicine 70(1): 94-118.

- 2002, The Cultivation of Whiteness: Science, Health and Racial Destiny in Australia, Melbourne University Press, Melbourne.

- 2006a, Colonial Pathologies: American Tropical Medicine, Race, and Hygiene in the Philippines, Duke University Press, Durham and London.

- 2006b, 'States of hygiene: race "improvement" and biomedical citizenship in Australia and the colonial Philippines', in Haunted by Empire: Geographies of Intimacy in North American History, Ann Laura Stoler (ed), Duke University Press, Durham: 94-115.

Attwood, Bain 2000, 'Space and time at Ramahyuck, Victoria, 1863-85', in Settlement: a History of Australian Indigenous Housing, Peter Read (ed), Aboriginal Studies Press, Canberra.

Bashford, Alison 2000, 'Is White Australia possible? Colonialism, race and tropical medicine', Ethnic and Racial Studies 23(2): 248-271.

- 2003, Imperial Hygiene: a Critical History of Colonialism, Nationalism and Public Health, Palgrave Macmillan, New York.

- and Maria Nugent 2002, 'Leprosy and the management of race, sexuality and nation in tropical Australia' in Contagion: Epidemics, History and Culture From Smallpox to Anthrax, Alison Bashford and Claire Hooker (eds), Pluto Press, Annandale: 106-128.

Blake, Thom 1993, 'The Leper Shall Dwell Alone': the Peel Island Conservation Plan: a Report for the Department of Environment and Heritage, Department of Environment and Heritage, Brisbane.

Briscoe, Gordon 2003, Counting Health and Identity: a History of Aboriginal Health and Demography in Western Australia and Queensland, 1900-1940, Australian Aboriginal Studies Press, Canberra.

Bryer, Linda 1988, Below the Magic Mountain: a Social History of Tuberculosis in Twentieth Century Britain, Oxford University Press, Oxford and New York.

Carey, Hilary M 1998, 'Subordination, invisibility and chosen work: missionary nuns and Australian Aborigines, c.1900-1949', Australian Feminist Studies 13(28): 251-267. 
ABORIGINAL HISTORY 2010 VOL 34

Cherry, Mark 1996, 'Bioethics and the construction of medical reality', Journal of Medicine and Philosophy 21(4): 357-373.

Cilento, Raphael 1920, Climatic Conditions in North Queensland: as they Affect the Health and Virility of the People, AJ Cumming, Government Printer, Brisbane.

- 1925, The White Man in the Tropics: With Especial Reference to Australia and its Dependencies, HJ Green, Government Printer, Melbourne.

- 1933, 'Leprosy in Australia and its dependencies', International Journal of Leprosy 5: 45-52.

- 1939, 'Leprosy in Queensland', International Journal of Leprosy 7(2): 201-208.

- 1944, Blueprint for the Health of a Nation, Scotow Press, Sydney.

- and Clem Lack 1959, Triumph in the Tropics: an Historical Sketch of Queensland, Smith and Paterson, Brisbane.

Cook, Cecil 1924, 'Leprosy in Australia', Medical Journal of Australia 2: 336-337.

- 1926, 'Leprosy problems', Medical Journal of Australia 2: 801-803.

Deacon, Harriet 2000, 'Racism and medical science in South Africa's Cape Colony in the mid- to late nineteenth century', Osiris 15: 190-206.

Edmond, Rod 2006, Leprosy and Empire: a Medical and Cultural History, Cambridge University Press, Cambridge.

Evans, Raymond 1989, 'Night of the broken glass: the anatomy of an anti-Chinese riot', in Brisbane in 1888: the Historical Perspective, R Fisher (ed), Brisbane History Group, Brisbane: 45-59.

Finnane, Mark 2007, 'Cilento, Sir Raphael West (1893-1985)', in Australian Dictionary of Biography, vol 17, Melbourne University of Press, Melbourne: 215-216.

- and John McGuire 2001, 'The uses of punishment and exile: Aborigines in colonial Australia', Punishment and Society 3(2): 279-298.

Fisher, Fedora Goud 1994, Raphael Cilento: a Biography, University of Queensland, St Lucia.

Gussow, Zachary 1989, Leprosy, Racism, and Public Health: Social Policy in Chronic Disease Control, Westview Press, San Francisco.

- and George S Tracy 1970, 'Stigma and the leprosy phenomenon: the social history of a disease in the nineteenth and twentieth centuries', Bulletin of Medical History 44: 425-449. 
Hammond, Philip 1985, 'Relic of lepers' suffering', Courier Mail, 23 September 1985: 9.

Holt, Albert 2001, Forcibly Removed, Magabala Books, Broome.

Hegarty, Ruth 1997, Is That You Ruthie?, Queensland University Press, St Lucia. Huggins, Rita and Jackie 1994, Auntie Rita, Aboriginal Studies Press, Canberra.

Jacobs, P 1986, 'Science and veiled assumptions: miscegenation in Western Australia, 1930-1937', Australian Aboriginal Studies 2: 15-23.

Jebb, Mary Anne 2002, Blood, Sweat and Welfare: a History of White Bosses and Aboriginal Pastoral Workers, University of Western Australia Press, Nedlands.

Johansen, Frederick A 1951, 'Advances in the treatment of leprosy', The American Journal of Nursing 51(7): 445-446.

Kidd, Rosalind 1994, 'Regulating bodies: administrations and Aborigines in Queensland 1840-1988', PhD thesis, Griffith University, Brisbane.

Kipp, Rita Smith 1994, 'The Evangelical uses of leprosy', Social Science and Medicine 39(2): 165-178.

Ludlow, Peter 1989, Peel Island: Paradise or Prison, Self-Published, Stones Corner.

Maguire, John 1991, 'The Fantome Island leprosarium', in Health and Healing in Tropical Australia and Papua New Guinea, Roy MacLeod and Donald Denoon (eds), James Cook University Press, Townsville: 142-148.

Markus, Andrew 1979, Fear and Hatred: Purifying Australia and California 18501901, Hale and Iremonger, Sydney.

Mawani, Renina 2003, "“The island of the unclean": race, colonialism and "Chinese leprosy" in British Columbia, 1891-1924', Law, Social Justice \& Global Development Journal 1, accessed 3 July 2009: <http:/ / www2.warwick.ac.uk/ fac/soc/law/elj/lgd/2003_1/mawani>

Mom, AM 1948, 'Promin in leprosy', Journal of Tropical Medicine and Hygiene 51: 85-86.

Moran, Michelle 2007, Colonizing Leprosy: Imperialism and the Politics of Public Health in the United States, University of North Carolina Press, Chapel Hill.

Obregon, Diana 2002, 'Building national medicine: leprosy and power in Colombia, 1870-1910', Social History of Medicine, 15(1): 89-108.

Parry, Suzanne 2003, "“Of vital importance to the community": the control of leprosy in the Northern Territory', Health and History 5(1): 1-21. 
Parsons, Meg 2008, 'Fantome Island Lock Hospital and Aboriginal venereal disease sufferers 1928-45', Health and History 10(1): 41-62.

- 2009, 'Spaces of disease: the creation and management of aboriginal health and disease in Queensland 1900-1970', PhD thesis, University of Sydney, Sydney.

Patrick, Ross 1987, A History of Health and Medicine in Queensland 1824-1960, University of Queensland Press, St Lucia.

Reynolds, Henry and Dawn May 1995, 'Queensland', in Contested Ground, Ann McGrath (ed), Allen \& Unwin, Crows Nest: 168-207.

Robertson, Jo 1999, 'In a state of corruption: loathsome disease and the body politic', PhD thesis, University of Queensland, Brisbane.

Rosenberg, Charles, and Janet Golden (eds) 1991, Framing Disease: Studies in Cultural History, Rutgers University Press, New Brunswick.

Rosser, Bill 1985, Dreamtime Nightmares, Australian Institute of Aboriginal Studies, Canberra.

Saunders, Suzanne 1989, 'A Suitable Island Site': Leprosy in the Northern Territory and the Channel Island Leprosarium, Historical Society of the Northern Territory, Darwin.

- 1990, 'Isolation: the development of leprosy prophylaxis in Australia', Aboriginal History 14(2): 168-181.

Stoler, Ann Laura 1995, Race and the Education of Desire: Foucault's History of Sexuality and the Colonial Order of Things, Duke University Press, Durham.

Vaughan, Megan 1991, Curing Their Ills: Colonial Power and African Illness, Stanford University Press, Stanford.

Watson, Joanne 1993, 'Becoming Bwgcolman: exile and survival on Palm Island Reserve, 1918 to the present', PhD thesis, University of Queensland, Brisbane.

Watson, Judy 1989, 'The hope of Boggo Road', Sunday Mail Magazine, 7 May 1989: 4.

Worboys, Michael 2000, 'The colonial world as mission and mandate: leprosy and empire, 1900-1940’, Osiris 15: 207-218.

Yarwood, AT 1991, 'Sir Raphael Cilento and the white men in the tropics', in Health and Healing in Tropical Australia and Papua New Guinea', Roy MacLeod and Donald Denoon (eds), James Cook University Press, Townsville: 49-51. 